\title{
Assessment of the Impact of Oil and Gas Resource Exploration on the Environment of Selected Communities in Delta State, Nigeria
}

\author{
Christiana Kayinwaye Omorede
}

Iniversity of Renin, ligeriia

\begin{abstract}
This Paper assessed the "Impact of Oil and Gas Resource Exploration on the Environment" of Delta State oil producing communities of Nigeria. It examined the problems associated with Oil exploration and its mitigation. Primary and Secondary data were used to source data for the set objectives. The theoretical framework was based on the resource curse theory and the environmental externalities theory. It was established that various problems such as oil spillage, retardation of vegetation growth, soil infertility, ill-health to members of the community, displacement of the people of the area, constant protestation of host communities, socio-economic deprivation, and perceived marginalization of the people are associated with oil resource exploration. This research concludes that the oil bearing communities have not adequately been compensated for harm done them through degradation of the ecosystem caused by several years of oil exploration. Their oil resource wealth has been turned to oil resource curse as they are disempowered, and condemned to perpetual underdevelopment. It is recommended that Federal Government should exert maximum efforts in assuring strict compliance of its legal instruments by the oil participating industries for a sustainable development in the region.

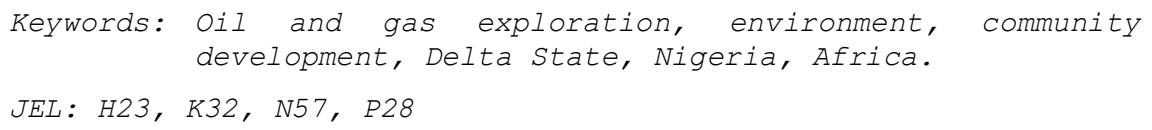

Various activities of Man on the surface of the earth lead to development have been acknowledged to be detrimental to the environment. This is exacerbated by rapid technological advancement particularly in the $21^{\text {st }}$ century. The oil bearing communities of Nigeria otherwise known as the Niger Delta region, is presently composed of nine-states. They include Akwa-lbom, Bayelsa, Cross- River, Rivers, Delta, Edo, Abia, Imo and Ondo States. The area is characterized by wetlands and water bodies with large mangrove forests and a network of creeks and rivers criss-crossing the entire region, with an

Manuscript received February 27, 2014; revised May 11, 2014; accepted May 26 , 2014.

Corresponding author: ckomorede@yahoo.com aquatic splendor. The large expanses of mangrove forests are estimated to cover approximately 5,000 to $8,580 \mathrm{~km}^{2}$ of land (Nwilo and Badejo, 2007) and they remain very important to the indigenous people of Nigeria as well as to the various organisms that inhabit these ecosystems. However, this region is daily subjected to a myriad of problems traceable to economic, social, and more worrisome is the heinous mismanagement of the environment by Multinational oil companies. This is because of its oil resources, the ecosystem of the area has been degraded and depleted in form of deforestation, depletion of mineral resources, destruction of aquatic lives, etc. The resultant 
International Journal of Management, Economics and Social Sciences

effect is manifested in different forms of sufferings such as in land displacement, economic backwardness, social unrest, diseases, and violent protestation in many communities where these companies are located. This paper contends that, before the discovery of crude oil in commercial quantity in Oloibiri (a creek town near Yanogoa the capital of Bayelsa) in 1956, the rich flora and fauna of the Niger-Delta area, supplied the immediate source of livelihood for the people of the region, and there was evident balance in the ecosystem. According to Efole (2004), World Bank Report of the Niger Delta declared that " the region had great potential to feed the entire population of the West Africa Sub-region and have sufficient commodities for exports". Some of these commodities highlighted by the report at the time included palm-oil and cassava, which were in abundance throughout the Delta. Uchebuaku (2006) stated that Nigeria contributes 3 percent of the World' s total oil production and was in 1999 rated the fifth largest source of oil by the World Bank. The export of crude oil makes up about 9 percent of the total exchange earnings of the country. In spite of the vast oil endowment, its immense potential for socio-economic growth and its contribution to the overall development of Nigeria, the oil producing region suffers a regrettable level of poverty and remain increasingly under threat from rapid deteriorating environmental conditions as well as social tension. The swamp and mangrove forests in the Niger Delta have lost their essence given the present ecosystem precipitated by the deliberate over exploitation of the oil resources. It is not an over statement to say that an ecological war is rapidly destroying Human life, flora, and fauna of the area and there is no greater threat on society and development than the continuous exploitation and sedimentation of our environment. The considerable endowment in oil resources has not translated into an enviable economic performance, but rather susceptible to the vagaries of the international oil markets. The effect of oil resource extraction on the Nigerian economy especially on Delta State of the Niger has been very glaring in terms of its negative effect on the region. Various works have attested to this assertion.

Eteng (1997) explained that oil exploration and exploitation has over the last four decades impacted disastrously on the social, and the physical environment of the Niger Delta oil bearing communities massively threatening subsistent peasant agricultural economy and environment as well as the entire livelihood and basic survival of the people. The deplorable way Oil and Gas resource are exploited overtime in Delta State is the bane of the region.

Saro Wiwa (1991) maintained over time that the environment in Ogoni land and other oil producing communities has been completely devastated by decades of reckless oil exploration and ecological welfare by shell and other Multinationals. This makes the situation in the Niger Delta region, a "paradox of plenty". World Bank Report (1995) in its observation highlights the point that despite its vast oil reserves, the Niger Delta region remains poor with education level below the national average. According to the report, while seventy percent (70\%) of Nigerian children attend primary 


\section{Omorede}

schools, the level in some parts of the Niger Delta has dropped with GNP below average of US $\$ 280$. The existence of multinational oil firms in this area does not equate the developmental level in the area rather; it appears that these firms only exist to take advantage of oil turnover, at the expense of the host communities. This assumption corroborates Bamet and Muller (1974) in their insistence that the primary interest of the global corporations is of worldwide profit maximization.

From the foregoing, the problem of this paper stems from the inept attitude of oil prospecting industries and the Nigerian government to effectively utilize resources accruing from the oil producing communities to develop the area and enhance their socio-economic status. The Nigerian state has benefited immensely from petroleum since it was discovered in commercial quantity in 1956. It is believed that oil which was first discovered in 1956 and first exported in 1958 accounts for more than 90 percent of Nigeria exports by value and about 80 percent of Government revenue, while the overall contribution of the oil sector to the national economy has grown from an insignificant 0.1 percent in 1959 to 87 percent in 1976 (CBN, 2000)

As at the year 2000, oil and gas exports accounted for more than 98 percent of export earnings and about 83 percent of Federal Government revenue, as well as generating more than 40 percent of its GDP. It also provided 95 percent of foreign exchange, and about 65 percent of government budgetary revenues, yet the area responsible for the nation's development are left out in any meaningful development projects, and are perpetually left in abject poverty, underdevelopment and deprivation. The awareness of displacement, marginalization and underdevelopment of the oil producing areas have been with the nation for more than four decades and successive governments have developed several initiatives to try to cope with the effects of suffering caused by oil exploration and exploitation on the host communities. However, none of these initiatives, so far seem to have been able to prevent the situation from escalating. The issue here is not in establishing multiple policies or agencies which in many cases do not go beyond political slogan, but what basic influence these policies or agencies has on the host communities. Against this background, it is the intention of this paper to assess the impact of oil and gas resources exploration on the environment and the people of Delta state of Nigeria.

To direct the course of this paper, attempt will be made to find answers to the following objectives:

\section{Objectives}

- To identify oil resources exploration activities on the environment.

- To determine the impact of oil resource exploration on subsistent agriculture, physical environment and social life of the host communities.

- To see to what extent the government and oil companies' efforts have mitigated in reducing the problems caused as a result of oil resource exploration in the host communities. 
International Journal of Management, Economics and Social Sciences

- To recommend other policy measures that will engender sustainable development in the region.

The introductory section above is followed by conceptual clarifications of major terms used in the paper. The rest of the paper is organized into five sections as follows; the literature review which presents the oil resource exploration and exploitation and the theoretical framework which relies on the resource curse theory and the externalities theory. These are followed by discussions of findings on the impacts of oil resource exploration on the environment of the host communities in Delta State, governments and oil companies efforts and problems militating against the management of oil resource problems, the conclusion and of course some recommendations to improve the needs of the people. The paper employs the analytical framework in its discussion.

\section{Conceptual Clarification}

For purpose of contextual understanding, below are some terms used in the paper that need operational definition and clarification.

\section{-Environment}

Environment is used in this paper to refer to the condition, or circumstances under which all living and non-living things occur naturally on Earth (Turner et. al., 1994). This includes: ecological units, vegetations, micro organisms, soils, rocks, seas, atmospheric and natural phenomena.

\section{-Environmental Degradation}

Environmental degradation in this work is the deterioration of the environment through depletion of resources, (air, sea/ water, and soil, the destruction of ecosystems and the extinction of wildlife, Stern et al., 1996). It also involves any change or disturbances to the environment perceived to be undesirable by the host communities and detrimental to their socioeconomic activities (Turner et. al., 1994). It is thus the reduction of the capacity of the environment to meet social, economic and ecological objectives, and needs of the people of Delta State.

\section{- Development}

Development is used here to mean the positive transformation or change of people' $s$ ways of living, attitudes, and behaviors as a result of their access to relevant and adequate services provided by government and government agencies (Waas et al., 2010; Camagni, 1998).

\section{- Oil Resources}

Oil resources here refer to non-renewable resources that take millions of years to be created under the surface of the earth (Nehring, 1978; Dam, 1976). They are referred to as non renewable resources because they can run out, or be used up. In Delta State, Oil resources are exploited from the soil in their crude form and are usually refined before they are used for their various purposes.

\section{- Oil Exploration}

Oil Exploration in this work deals with the search for oil and gas by petroleum multinationals for hydrocarbon deposits beneath the Earth' $s$ surface (Forsythe, 1996; Omofonmwan and Odia, 2009). Exploration is a highly sophisticated technology that involves a gravity of magnetic survey; passive seismic or regional seismic 


\section{Omorede}

reflection survey which works on the principle of the time it takes for reflected sound waves to travel through matter (rock) of varying densities and using the process of depth conversion to create a profile of the substructure. Offshore and remote area exploration in Delta state is generally only undertaken by very large corporations or Nigeria' s government.

\section{- Oil Exploitation}

This is a process in which usable petroleum is extracted and removed from the ground (Link, 1952). It also involves seismic activities resulting in the degradation of the environment in form of depletion, oil spills and deforestation, without regard to its regeneration to the impoverishment of the host communities (Garland et al., 1990). Both exploration and exploitation degrade the environment in varying capacity and they are used interchangeably in this work.

\section{- Gas Flaring}

Gas Flaring is the process of separating and burning of the gas produced from pumped oil resource from the ground (Elvidge et al., 2009). This is done by burning the separated gas in massive flares as waste (into the air/ environment)

\section{LITERATURE REVIEW}

It is necessary to review some existing literature on the aspects of the impact of oil exploitation as many works have been done by various scholars and experts in this topical area (Elvidge et al., 2009). The quality of the environment is critical to the survival and sustenance of human existence in particular and animals and plants in general. No wonder Awodola (1997) ranked environmental degradation as second to economic depression, as one of the problems the world is currently facing. Tyonongo (2008: 34) states that " environmental degradation is critical because the ability of the environment to support and sustain life depends on the proper natural balance of its properties; soil, water, air, plants and animals." He further posits that " the environment has to possess the right temperature, needed oxygen and carbon dioxide in its atmosphere, good rich soil, water of its rivers, lakes, oceans and precipitation, vegetation and all other conditions that are necessary for the sustenance of life."

Oil resource exploitation which involves various chemical and seismic wave generations is a major source of environmental degradation particularly through liquid discharges and oil spills as well as gas flaring. Thus, various materials are released into the environment in the course of oil production operations. Petroleum renders the soil infertile, burns vegetation and kills useful soil organisms thereby hampering agricultural output and productivity. Ajakaiye (1985) and Adekoya (2003) in their work argue that before mineral resources are harnessed, they pass through the stages of exploration, mining and processing; different types of environmental damages and hazards inevitably accompany these three stages of mineral development. Their arguments further posit that petroleum consists of complex mixtures of aliphatic, alicyclic and aromatic hydro carbons, as well as polar organic compounds. These components may be transformed into other structures on entering the environment. 
International Journal of Management, Economics and Social Sciences

Oil spills, (either in crude or refined form), natural gas flaring and deforestation which are highly associated with Oil extraction are common phenomena in the oil communities and have caused severe environmental degradation in Delta state. This is because they contaminate the environment and cause water and land pollution with grave consequences on both human health, aquatic and terrestrial life due to the toxic nature of the chemical discharged (Wild, 1996). Besides once the environment is contaminated, it remains a potential threat for many years. For instance, fishes living in surface waters are killed as a result of which fishermen in such areas have lost their means of livelihood. Also, when there is an oil spill on water, spreading immediately takes place and the gaseous and liquid components evaporate. Some get dissolved in water and even oxidize, and yet some undergo bacterial changes and eventually sink to the bottom by gravitational action. The soil is then contaminated with a gross effect upon the terrestrial life. As the evaporation of the volatile lower molecular weight components affect aerial life, so the dissolution of the less volatile components with the resulting emulsified water, affects aquatic life (Akpofure et al., 2000).

In Nigeria, about 62.8 percent of the oil spill incident occurred on farmlands (Nwankwo and Ifeadi, 1988). A major impact being the reduction in the availability of fish products and this has also made them very expensive. Statistics also indicate that a total of 9,107 oil spill incidences occurred in Nigeria between 1976 and 2005 resulting in about $3,121,909.8$ barrels of oil spilled into the environment (Odu and Offodum,
1986). Some of these major spills include; the Escravos spill (Funiwa-5 blow out) of over 400,000 barrels of oil spreading through the Delta region polluting about $1,200 \mathrm{~km}^{2}$ (Nwilo and Badejo, 2005). In the disaster about 180 people died while 300 people contacted various illnesses through drinking polluted water and eating contaminated food in the affected areas (Nwilo and Badejo, 2005). In 1986, it was estimated that eight major creeks and villages were affected. Several thousand barrels of oil were lost and economic activities paralyzed in the affected areas. The damage done to fish ponds, nets and traps of the farmers was said to be over two million Naira (Odu and Offodum, 1986; Nwankwo and Ifeadi, 1986; Nwilo and Badijo, 2005). Also the Jesse spill of 1998 resulted in the fire incidence that claimed over a thousand lives and ravaged the fragile ecosystem.

Fagade (1981), Ikporukpo (1988), UN System (2001) and Jaiyeoba (2002), all agreed to the considerable adverse effects on soil, water, resources and animal life due to the toxic nature of chemicals discharged from oil spills. Oil spills have also led to extensive deforestation with inadequate replanting practices. Essoka, Ugbogu and Uzu (2006) found heavy metal concentration in Warri area of Nigeria and that the oil industry constituted a potential hazard to its immediate environs due to the high levels of heavy metals observed. Agriculture which is the main stay of the rural economy of the area is therefore threatened and human life invariably in danger. The table below presents oil Spill data of shell Petroleum Development Company from 19952005 (SPDC). 


\section{Omorede}

\begin{tabular}{ccc}
\hline Year & No. of Spills & $\begin{array}{c}\text { Volume in Barrels } \\
\text { (bbl) }\end{array}$ \\
\hline 1995 & 235 & 31,000 \\
1996 & 326 & 39,000 \\
1997 & 326 & 39,000 \\
1998 & 240 & 80,000 \\
1999 & 248 & 50,000 \\
2000 & 320 & 20,000 \\
2000 & 330 & 30,100 \\
2001 & 302 & 76,960 \\
2002 & 262 & 19,980 \\
2003 & 221 & 9,916 \\
2004 & 236 & 8,317 \\
2005 & 224 & 11,921 \\
Total & 2,944 & 377,194 \\
\hline
\end{tabular}

Source: Shell Nigeria Annual Reports (SNAR), 2005.

Table 1. Oil Spill Data SPDC 1995-2005

Other studies such as the study by Ekpo and Udotong (2004) on air quality precipitation and corrosion of Mbo Local Area of Nigeria showed that the concentration of carbon monoxide, methane and volatile organic compounds were above 0.01 percent and less than $0.01 \mathrm{ppm}$ respectively, which is above the regulatory standards. The acidic $\mathrm{PH}$ value of rain water in the area indicated acid rain caused by oil and gas activities in general and gas flaring in particular. They further reported that the gas flare caused corrosion of zinc roofing sheets, contributed to low agricultural productivity, high mortality of aquatic animals, reduction in fishing and farming activities, socio-economic activities and ultimately impairment of human health, poverty, underdevelopment and bitterness amongst other effects. This finding is consistent with the contention of Ross (2001) when he posited that adverse health outcomes and impacts of environmental degradation include; direct effects of increase in road traffic accidents and destitution (which accelerates HIV and other sexually transmitted diseases).

In the same way, Oil resource exploitation in oil bearing communities has been reported to have affected the health of the local people. In addition, systematic effects interact to determine broader consequences on health, such as higher rates of child mortality, lower life expectancy, higher malnutrition rates or lower spending levels on health care. A corollary study by Sebastian and Hurting (2004) on the potential health impact of oil pollution on women living near oil fields, also observed that such women exhibit symptoms, such as skin mycosis, tiredness, itchy nose, sore throat, headaches, red eyes, ear pain, diarrhoea, and risk of spontaneous abortion was high among these women. Similarly, a higher incidence of cancer was discovered among males and females in areas where oil exploitation has been going on for at least 20 years. The report also stated that children were observed to have an increase in hematopoietic cancers while many children also had distended bellies and light hair (Tyonongo, 2008). These are evidences of kwashiorkor; a protein deficiency syndrome.

The peculiar nature of the environmental degradation is also in its global nature. This is because pollution created in one country has an impact on another. For instance, the destruction of one part of the ozone layer by one nation has an impact on all nations. This explains why the issue of environmental problems has become global one requiring all and sundry to show concerted concern for the benefit of mankind. Unfortunately in Nigeria, lax environment regulations, and government complicity 
International Journal of Management, Economics and Social Sciences

(particularly during the military rule), are also some of the problems associated with the high level of the Delta ecosystem depletion. Sustainable development, management and improvement of the environment play significant roles in the prosperity or depression of the society. For instance, with respect to agriculture which is one of the most basic sectors of the nations' economies, it is a common knowledge that poor soil will result in poor farming and poor living. Conversely, with good soil, good farming and good living. The decline of ancient civilizations on Mesopotamia, the Mediterranean and pre-Columbian America is believed to have strongly been influenced by natural resource degradation from non-sustainable farming and forestry practices (Tyonongo, 2008). Emoyan, Akpoborie and Akporhonor (2008) established that since the commencement of Oil and gas exploration/exploitation activities in the region, the region has social, economic, health and ecological destabilization, and significant reduction in terrestrial and aquatic life. In another work, Owabukeruyele (2000) argues that though oil has contributed remarkably to foreign exchange of the country, on the other hand, its negative impact on socio-economic life on the immediate oil bearing communities and its inhabitants has left a balance sheet of ecological and social physical disaster. Jimoh and Aghalino (2000), and UNDP (2006) claim that the Niger Delta is a region suffering from administrative neglect, crumbling social infrastructural facilities and services, high unemployment, social deprivation, abject poverty, filth and squalor, and endemic conflict. The paradox is that the region that contributes so much to the national economy is ravaged with the highest level of poverty resulting from extensive oil resource exploration and exploitation which have deprived them of their traditional economic activities such as farming and fishing. While the region is the treasure base of the country, it is paradoxically Nigeria' s socio-economic poverty enclave with growing youth unemployment, displacement and perceived discriminatory practices against the indigenes by oil companies. Obi (2009) observed that this situation has deepened the tension in oil producing communities in the Niger delta. The agitation of ethnic minorities was partly because the economic crises and reforms had deepened the exploitation and impoverishment of the NigerDelta people, while the democratic institutions had failed to address the roots of the widespread grievances in the region. In a similar report, Efole (2004) noted that of the two most appropriating external systems, (the Government and the multinational oil companies) the oil companies are in more direct and physical contact with the communities and their expropriated inhabitants. The deprived peasants currently make demand for social services from the oil companies, than they can make from the often-inaccessible Nigerian State. This has always led to conflicts as the oil companies are engaged in the process of collaborating with the Nigerian regime to use violence as a means of placating the protesting communities. He further reported that the conflict that has emerged in Isoko as a result of the extraction of oil resource has its roots in the violation of the promulgation of obnoxious 


\section{Omorede}

legislation and the cumulative effects of poverty among the people.

In Nigeria, several policy instruments have been promulgated to ameliorate environmental degradation, at Federal and state levels. These include; the establishment of department of environmental sciences and technology in some of the nation's Universities, Polytechnics and Colleges of Education amongst others. The initiatives to improve the environment notwithstanding, it still appear to be in a very sorry state. For instance, Nigeria government has for long acknowledged the wasteful effects of gas flaring, hence in 1984 prohibited gas flaring. Nonetheless, various deadlines for its cessation have not been met as each deadline has passed and flaring continues. The work of Jimoh and Aghalino (2000) particularly focused on government efforts towards tackling the problem of degradation caused by oil and gas industries in Nigeria. They observed that exploration activities involves vegetation clearing and release of waste which eventually reduce land availability for agricultural cultivation. They also identified that the laws and regulations were only policy statements that are not implemented. The rate of environmental degradation is still progressing at an alarming pace, threatening humans, animals, and plants production and economic prosperity. Successive years of bad governance and corruption are perhaps responsible for the continued absence of proper environmental management in the region even in the face of visible evidence of degradation.

The literature reviewed above highlights environmental, socio-economic and health hazards that accompany oil resource exploitation. This shows that most works have been done on the impact of oil exploitation on the environment. Nonetheless, the literature appears not to have adequately addressed the issue of displacement, deprivations and marginalization of the rural inhabitants of the Aja-Omeatan people of Warri North and environs, or the Irri people of Isoko North. There are also gaps identified in government' $s$ efforts in mitigating the effects of unemployment caused by displacement of land owners and farmers which include the youths of the area. These indicate some gaps in literature which this paper intends to fill.

\section{Theoretical Framework}

In this paper, two theoretical frameworks which in the consideration of the researcher are appropriate in exposing the very many problems caused by oil resource exploitation to the environment in the Niger Delta are used. They are the issue of paradox of plenty, otherwise known as the "Resource Curse" theory, and the "Environmental Externalities" theory.

The "resource curse" theory, presupposes that nations with rich natural resources may fail to develop in other sectors ultimately bringing about financial problems. The theory also assumes that such a country will also fail to develop infrastructure and other industries; instead they focus on a handful of industries which cripples the economy by encouraging very isolated investments and development; while ignoring the need to develop a more diversified economy. The result is that the country is also forced to a large extent to rely on other nations for a wide variety of goods and services; and may in fact end up 
International Journal of Management, Economics and Social Sciences

with a net loss at the end of the year (Auty, 1993). The term resource curse was first used by Richard Auty (1998) to describe how Countries rich in natural resources were unable to use that wealth to boost their economies and how counter initiatively; these countries had lower economic growth than countries without an abundance of natural resources. This was exemplified with the "Dutch Disease" syndrome, a situation which makes it difficult to diversify the economy, generally undermining non-oil activities. Numerous studies including one by Sachs and Warner (2001), and Billon (2001), have all shown a link between natural resource abundance and poor economic growth. Hardin (1968) on his part opines that in the traditional Commons Problems, free access to a finite resource ultimately dooms the resource through over exploitation. Natural resources can and often do provoke conflicts within the society as different groups and factions fight for their share as expressed by Collier and Hoeffler (2002). This tends to erode government' $s$ abilities to function effectively.

The theory of negative externalities is very fundamental in the analyses of environmental economics. This is because pollution in any form is known to result in harm to both people and the environment. Externalities are benefits or costs generated as an unintended outcome of an economic activity that do not accrue directly to the parties involved in the transaction and where no compensation takes place. They manifest themselves through changes in the physicalbiological environment. Positive externality arises when actions of an individual or a group confers to others positive effects or reward. A technological spill over is a positive externality which occurs when a firm' s invention not only benefits the firm but also enters into the society' s pool of technical knowledge and benefits the society as a whole. On the other hand, pollution is a negative externality which occurs for instance, when a factory discharges its untreated effluents in a river, the river is polluted and consumers of the river bear costs in the form of health costs or/and water purification. Alfred Marshall (1842 to 1924) noted to have introduced the externality theory in economics, but his theorization was only concerned with positive externalities accruing to the third parties outside of transactions (see Marshall, 2009). In the 1920's, Pigou propounded the negative externalities theory having realized that externalities contained not only benefits but also costs. Pigou (1920) externality theory deals with the problem of smoke emission by a factory damaging nearby business or residents. His solution for correcting the negative externality is to impose a per unit tax on output to the firm generating the negative externalities. The per unit tax should be equal to the differences between the social marginal cost and the private marginal cost corresponding to the social optimal output, the output satisfying the condition the price equals the social marginal cost. Imposition of such a tax will raise the output price and reduce the demand thereby helps in internalizing the environmental costs to some extent in the decisions of producers and consumers of the product. Pigou recognizes that sometimes, government may find it necessary to exercise some means of authoritative control. Negative 


\section{Omorede}

externality theory as has been described earlier, arises when the welfare of one party is adversely affected by the action of another party and the loss in welfare is uncompensated for due to a lack of liability to third parties who suffered the damages. Others like Baumol and Oates (1988) Coase (1960), and Meade (1973) also identified the conditions for terming an event an externality. For instance, a situation where actions affect the production possibilities of the economy and the welfare of people who are not fully consenting parties in reaching production decisions, as they are in sales and purchases (Meade, 1973). No compensation is made for welfare losses and gains. It is the negative externality theory as exposed by Pigou that is very relevant to this paper. This paper argues that government should mandatorily implement the legislation required for the oil industries to practice all necessary precautions that will prevent or minimize environmental damages, while the ones already in existence should be strengthened and upheld.

\section{METHODOLOGY}

This study adopted the qualitative phenomenological methodology. Two main sources, namely the Primary and Secondary sources were used to collect data for the paper. The primary sources included personal interviews and direct observations. Through the structured interview, the opinion of participants on their experiences as members of communities where Oil and Gas exploration has been carried out overtime was sought. The aim was to get data from participants (members of the host communities) and describe their lived experiences on the impact of oil resource exploitation on the people of Delta State of Nigeria. Interviews and observations were thus used to identify different types of environmental problems of oil resource extraction, the various ways of preventing or reducing them, and their impact on the environment of the host communities. "Qualitative research is an inquiry process of understanding based on distinct methodological traditions of inquiry that explore a social or human problem. The research builds a complex holistic picture, analyzes words, reports detailed views of informants, and conducted the study in natural setting" Creswell (1998: 15). The structured interview questions were designed and generated by the researcher to elicit response on the impacts of oil exploration on host communities. The formulation of questions by the researcher relied on face validity in determining the constancy and transferability of the questions in line with other qualitative researches (Rossman and Rallis, 1998), and the use of phenomenological methodology allowed the researcher go further than her personal knowledge (Creswell, 2009). The questions only required Yes or No option by ticking the accepted option. The questions were modified from Bankole, and Owoseni (2010). It was designed in the yes/no format for an easy response as arranged in line with Respondents' views on their perception on the following: Intensive oil resource degradation generation, effects of intensive oil exploration on socio-economic activities, and compensations paid by oil industries to host communities. The three structured questions are as follows: (1) Activities 
International Journal of Management, Economics and Social Sciences

of Oil resource exploration and exploitation generally generate pollution and waste into the environment. (2) Intensive oil resource exploration /exploitation limit farming /fishing and other traditional means of the people, and have made drinking water scarce. (3) Oil producing industries do not pay compensations for damages caused by oil spill gas flare and other damages caused by oil exploration and exploitation activities. Sample was made up of 40 respondents from each zone. The 40 respondents were interviewed, bringing the total number of respondents to 120 persons. The secondary sources included published books, journals, News papers and the internet. Information and data gathered from existing documents and records pertaining to oil, Delta state, environment and developmental issues was also sourced through the secondary source. The scope of the paper is limited to oil producing communities and environs of Delta state of Nigeria. The reason is that Delta State is a major oil producing state and ranks second to Rivers state. The state supplies about 35 percent of Nigeria' s crude oil and some considerable amount of natural gas (Nigeria Galleria, 2012).
Ethiope-West, Sapele, Ndokwe-East and Ndokwa-West. The Nation' s second Refinery as well as the petrochemical plant is located in the state at Warri. To arrive at the three zones used for the study, the purposive sampling method was used to select Warri environs (Zone A), Sapele area (Zone B), and Isoko South local government areas (Zone C) respectively. Data were drawn from the three selected zones using structured interviews. The purposive sampling was used because it allowed the researcher to select sample on the bases of her knowledge of the population, its elements and the nature of the research objectives. Data collected from respondents were tallied and separated for a thorough analysis. The descriptive and narrative analyses were adopted for discussions. The descriptive statistics included tables, frequency distribution and simply percentages. Data from both primary and secondary sources were analyzed qualitatively. All analysis was used to draw conclusions and to make recommendations.

\section{RESULTS}

Table 2 below presents the report of an interview

\begin{tabular}{ccccccc}
\hline \multirow{2}{*}{ Response } & \multicolumn{2}{c}{ Zone A (Warri Environ) } & \multicolumn{2}{c}{ Zone B (Sapele Environ) } & \multicolumn{2}{c}{ Zone C ( Isoko Environ) } \\
\cline { 2 - 7 } & Frequency & Percentage & Frequency & Percentage & Frequency & Percentage \\
\hline Yes & 36 & 90 & 35 & 87.5 & 35 & 87.5 \\
No & 4 & 10 & 5 & 12.5 & 5 & 12.5 \\
Total & 40 & 100 & 40 & 100 & 40 & 100 \\
\hline
\end{tabular}

Source: Field Survey 2012.

Table 2. Intensive Oil Resource Exploration Degradation Creation. (Activities of oil resource exploration and exploitation generate pollution and waste into the environment)

The oil producing local government areas are Warri-North, and Warri-South, Burutu, IsokoNorth and Isoko-South, Okpe, Ethiope-East and with some people from oil resource host communities. The analysis of the result of interview carried out in table two above, indicated 
Omorede

that in Zone A 90 percent of the respondents to the "No" option. It can therefore be inferred were aware that as a result of the daily activities that majority of them agreed that their farm and of gas and oil resource exploration industrial fishing activities were disturbed which limited their pollutions were generally generated while only 10 economic potential. It was quite easy to observe

\begin{tabular}{ccccccc}
\hline \multirow{2}{*}{ Response } & \multicolumn{2}{c}{ Zone A (Warri Environ) } & \multicolumn{2}{c}{ Zone B (Sapele Environ) } & \multicolumn{2}{c}{ Zone C ( Isoko Environ) } \\
\cline { 2 - 7 } & Frequency & Percentage & Frequency & Percentage & Frequency & Percentage \\
\hline Yes & 35 & 87.5 & 38 & 95 & 35 & 87.5 \\
No & 5 & 12.5 & 2 & 5 & 5 & 12.5 \\
Total & 40 & 100 & 40 & 100 & 40 & 100 \\
\hline
\end{tabular}

Source: Field Survey 2012.

Table 3. Effects of Intensive Oil and Gas Resources Explorations and Socio-Economic Activities. (Intensive oil and gas resources exploration limit farming/fishing and other traditional activities of the people and has made drinking water scare.)

percent of them were not aware. In zone B oil film floating on the waters observation also (Sapele environs) 35 respondents representing showed that the vegetation in most areas has 87.5 percent responded to the "Yes" option been damaged.

while 5 of them responded to "No" which Table 4 revealed that larger percentage of represented 10 percent. In zone C (Isoko respondents from the zones accepted that environs), 35 respondents answered in the multinational oil companies do not pay affirmative. From this it can be deduced that compensations. The inference drawn from this is

\begin{tabular}{ccccccc}
\hline \multirow{2}{*}{ Response } & \multicolumn{2}{c}{ Zone A (Warri Environ) } & \multicolumn{2}{c}{ Zone B (Sapele Environ) } & \multicolumn{2}{c}{ Zone C ( Isoko Environ) } \\
\cline { 2 - 6 } & Frequency & Percentage & Frequency & Percentage & Frequency & Percentage \\
\hline Yes & 32 & 80 & 30 & 75 & 22 & 55 \\
No & 8 & 20 & 10 & 25 & 18 & 45 \\
Total & 40 & 100 & 40 & 100 & 40 & 100 \\
\hline Source: Field Survey 2012 & & & & &
\end{tabular}

Table 4. Compensations Paid By Oil Industries

(Oil producing industries do not pay compensations for damages caused by oil spill, gas flare and other damages caused by oil exploration and exploitation activities.)

larger percentage of the respondents are aware that oil and gas resources exploitation activities contribute to the problem of environmental degradation.

The result of interview in table 3 (at top of the page) showed that a larger percentage of respondents agreed that intensive oil and gas exploration interfered with their socio-economic activities, because only a few of them responded that oil companies who directly cause harm to the environment did not pay them for such damages.

Personal observations in the 3 Zones respectively also found that because the natural environment has gravely been degraded most of the people have relocated elsewhere in search of greener pastures. It was therefore established that oil extraction and related operations of the multinational oil corporations pose a serious 
International Journal of Management, Economics and Social Sciences

threat to the survival and livelihood of the oil producing communities in Delta state as some of them have been displaced from participating in their socio-economic activities. In addition, social conditions such as disharmony, and rivalry due to intense competition for scarce farmlands or fishing grounds, generate disaffection and antigovernment sentiments in the host communities. Youth restiveness and violent protestation is not unconnected with these problems. Findings also revealed Aja-Omaetan community in Warri North government area of Delta state as a good example of protestations by the people of the region in the past. To register their resistance to the pollution of the environment caused by the activities of the Oil Companies, the people of Aja-Omeatan gave American oil giant Chevron Nigeria Ltd (CNL), a 30 day ultimatum to carry out an Environmental Impact Assessment (EIA) and pay adequate compensation to the community for the destruction of their water front and shores in July 2011. They contended that the water front and shore of the Community, being gateways to the creeks and Dibi Field operated by the oil firm, has been damaged and destroyed by oil exploration activities of the company in the area. In a petition by their Lawyer, Francis Akumagba and Co. to the Managing Director of CNL, the people indicted the Company for gas flaring which has affected them seriously as it impacted negatively on the Environment and their means of livelihood (Harris-Okon, 2011). The gas flare has led to scorching heat in the Community which in turn has made life uneasy and unbearable for them, while fishing activities have been greatly impaired. They also either complained of their inability to farm or go fishing. This is because fishes in their rivers were extinct and that rush plant, grown and found in the Community for making mats and other economic materials, had withered as a result of the never ending gas flares emanating from CNL operations in Dibi Field.

They further contended that Aja-Omaetan, being a gateway to Dibi Field, their creeks and water-ways were plied daily by sea truck operated by CNL which were "ruggedly driven and create heavy waves that damage and destroy shore and water front' $s$ of the community. The people also recalled that two meetings held at the instance of the special Adviser to the Governor of Delta State on Oil and Gas with CNL failed, as the Oil Company refused to comply with the decisions reached that there should be an Environmental Impact Assessment and payment of compensation by the Company to the Community (Harris-Okon, 2011).

In 2010, Women in protest took over the Escravos Chevron-Nigerian Government Gas pipeline project to address their concerns. The women demanded Shore protection. According to one of the interviewed respondents, Madam Mercy Olowu Ugborodo women leader lamented on the devastating impact of decades of oil exploration and exploitation on the communities. She stated as follows; " things have remained the same here since / was 15 years old. Nothing has changed except that the oil Companies activities has spoilt our land and caused untold hardship to the people. We can no longer bear this brunt".

Similarly, the Chairman of Ugborodo 


\section{Omorede}

Communities, Chief Thomas Ereyitobi, stated that

" their reasons for filing their protest, is that the affected Communities want Shore piling for erosion control as well as step down line for industrial electrification" .

Ogoigbe' s (2012) report also revealed that 64 Itsekiri Communities in Warri South West and Warri North Local Government Areas of Delta State were affected by a devastating oil spill at Bonga Field, on $20^{\text {th }}$ December 2011. This, they claimed has disturbed their fishing and economic activities as oil spill flowed to their village fishing areas disturbing fishing activities, staining their fishing materials, vegetations, and killing aquatic lives. The spill was estimated at about 40,000 barrels. Though, they have called on the management of shell Petroleum Company (SPC) to discuss modalities on enumerated clean-up and how relief materials will be sent out to the victim, no positive response was received. In another community, Chevron Abiteye flow station oil spill of over 1,500 barrels rendered over 10 ljaw Communities homeless. About five hundred persons in Gbaramatu Kingdom in Warri South West Local Government area of Delta State were also affected by the spill (Arubi, 2007). This has also led to anger and fresh threats to the peace and security in the area, as the Community accused Chevron Nigeria Limited, of employing divide-and-rule tactics in dealing with the problems arising from the spill. They argued that compensation should be paid directly to victims instead.

\section{DISCUSSION}

In a good government, the exploitation of oil resources is expected to generate larger revenues to foster development and reduce poverty for the people. But a weak government characterized with ineffectiveness, corruption, and conflicts, poverty will certainly strive. Finding is in line with the negative externality theory as propounded by Pigou (1920). Pigou realized that externalities also contained costs. The cost of oil exploration in Delta state of Nigeria is that the people suffer from abject poverty as a result of government' $s$ failure to effectively exercise control over the implementation of adequate compensation due the host communities who has been deprived of their traditional economic activities of farming.

Findings revealed that the Nigerian oil industry has affected the country in a variety of ways at the same time. On one hand, it has fashioned a remarkable economic landscape for the country, on the other hand, when considered in respect of its negative impact on the socio- economic life and the environment of the immediate oil bearing communities and its inhabitants, it has left a balance sheet of ecological and socio-physical disaster. This revelation corroborates Owabukeruyele (2000) who argued that oil resource has both positive contribution and negative contribution to the Nigerian socioeconomic life of the people. Oil 'exploration' has over the past four decades had a ruinous impact on the physical environment of the oil bearing communities in Delta State, extremely threatening the subsistence peasant economy, the environment and the entire livelihood and basic survival of the people. Their vegetation have been damaged, the ecology distorted and depleted, their natural landscape; eroded and 
degraded. This corroborates Wild (1996: 189210), Nwankwo and Ifeadi (1988), Odu and Offodum (1986), Fagade (1981), Ikporukpo (1988), UN (2001), Jaiyeoba (2002) and Meades (1973). They all agreed to the considerable adverse effects of toxic nature of chemicals discharged from oil spill on soil, water, resource and animal life.

Findings also revealed that gas flaring is an oil resource exploration degradation activity which involves tremendous wasteful and environmental damages. This has been going on in the area as long as oil exploration itself. The effects being that gas that should have been converted to funds to manage the environment has turned to environmental problems for the oil bearing communities to the extent that they hardly can sleep at night as gas is also flared into the air all night long. This agreed with the resource curse theory. Suffice to say that, oil resource exploitation has caused socio-economic and environmental problems in Delta State such that the environment of the host communities and their subsistence fishing and farming, are hardly practiced. Oil exploration appears to be the only viable economic activity in Delta state. This corroborates the resource curse theory of Auty (1993). Nigeria has focused on oil resource alone rather than farming which was hitherto the main stay of the Niger region. Another finding, points to the fact that due to the numerous oil generated environmental pollution evident throughout the region, farming, and fishing have become impossible or extremely difficult in these communities, even drinking water has become scarce and diseases appeared common. These also corroborates Emoyan et al. (2008), Jimoh and Aghalino ( 2000) and UNDP (2006) who agreed in their various studies that the region suffers social, economic, health and ecological destabilization as well as administrative neglect crumbling social infrastructural facilities, high unemployment, social deprivation, abject poverty, filth and squalor and endemic conflicts.

Finding also revealed that Government and Oil Companies efforts in the management of problems caused by Oil Resource Exploitation in Delta state of Nigeria is not adequate. This is very fundamental to the constant protestation of the displeased youth of host communities. This is corroborative of Obi's (2009), Efole' s (2004), and Collier and Hoeffer (2004) believe that deprived farmers and youth make demands for social services which usually led to conflicts. In recognition of the dangers posed by poor management of environmental issues caused by Oil resource exploitation, Government has made some efforts towards development and management of the Niger Delta; this has resulted in the enactment of various environmental laws and the creation of agencies to regulate the environmental consequences of oil resource exploitation. These laws are in the form of acts or decrees, policies, and treaties. Treaties are involved when it has to do with international or multinational agreements. For instance, Nigeria is a signatory to series of International environmental based agreements, such as the Biodiversity Climate Change, Climate Change Kyoto Protocol, and Desertification. The 


\section{Omorede}

International agreements give credence to the fact that environmental problems observe no national boundary. Beyond this, Nigeria's Government also has various locally developed instruments of intervention to manage, monitor, and implement various policies meant to mitigate oil resource exploitation on the environment. They include among others the following: (UN Agenda 21-Nigeria, 1997) the National guidelines and standards for Environmental Pollution Control in Nigeria of 1991, National Effluent Limitation Relations, S.I.8 of 1991; Pollution Abatement in Industries and Facilities Generating Wastes Regulations S.I.9 of 1991; Wastes Management Regulations S.I.15 of 1991; and Sectoral Guidelines for Environmental Impact Assessment (EIA), while the Federal Ministry of Water Resources and Rural Development, Federal Environmental Protection Agency (FEPA), Nigeria Institute of Oceanography and Marine Research (NIOMR), Niger Delta Development Commission (NDDC), National Emergency Management Agency (NEMA) are other monitoring and implementation agencies relating to mitigation of disasters. Unfortunately in a weak government, characterized with corruption and non commitment of political will to actualize policies, it will be difficult to use resources meant for development judiciously. This has eroded government' $s$ ability to function effectively. This is in agreement with Sachs and Warner (2001) and Billon (2001). They all have shown a link between natural resource abundance and economic growth.

The roles of NDDC as enshrined in the NDDC (establishment etc.) Acts 2000 were basically to offer a lasting solution to the socio-economic difficulties of the Niger Delta region, the core concern being that of development and well being of the citizens of the Niger Delta. However, this Organization which has generally been regarded as a vehicle of corruption and fraud has not been able to achieve its sole mandate. This agreed with the recent rating of the NDDC by Nigeria' s Senate who considered the body " a big failure" (Akogun, 2011). The case of the NDDC is replete in all the other intervention outfits before it; hence much is still left to be desired as far as mitigation is concerned. Non commitment to political will is also a big problem militating against the management of the environment in the Niger Delta as government hardly does what it says it will do. The case where government has been shifting grounds on the commencement date of the cessation of gas flare is quite disturbing. There must be enough political will to actualize policies if we must progress. Although some Oil Company Operatives have taken some palliative measures such as; in the establishment of some health centres, and in the provision of free medical facilities and services, several unmitigated situations have provoked frustrations that led to youth restiveness in the region. The realization of the attendant exploitation and neglect in the midst of plenty, informs the militia attacks, kidnaps, and hostage taking. There is therefore need for adequate management of the environment and development so that future generation will not be condemned to perpetual displacement of their original habitat. More so, there should be compensation to the oil resource 
International Journal of Management, Economics and Social Sciences

bearing communities, who have for long been marginalized, exploited, displaced, neglected and deprived. Focus should be in the area of provision of social amenities, youth employment, physical infrastructures, education, health, communication, power, etc.

\section{CONCLUSION}

The social and environmental costs (destruction of wildlife and biodiversity, loss of fertile land etc.) of oil resource exploration and exploitation have been extensive to the Delta state oil producing communities and indeed the entire oil bearing communities in Nigeria. This paper argued that environmental degradation caused by intensive oil exploitation does not only exacerbate the collapse of socio-economic activities induced by oil spillages, gas flaring, deforestation and other such activities of oil industries but had also displaced many from their farming activities without providing possible alternatives. They have not only been subjected to their lands being taken over by the oil companies, but have also been inadequately compensated for harm done them through degradation of the ecosystem caused by several decades of oil exploration and exploitation of the oil resources. We argue that government' $s$ inability to fully define and enforce mitigation rights and policies has pressurized the inhabitants into resorting to crisis perhaps to drive their point home. The Nigerian government has been able to build its economy through the benefits accruing from oil exportation at the expense of the Niger Delta who bear the social costs. These social costs in the form of air and water pollution, corrosion of materials and destruction of aquatic life, farms, flora and fauna; consequently human life and the environment are affected from damages which are also inadequately compensated for. They are thus deprived from participating actively in their traditional economic activity which is mainly farming on land or fishing in the waters. Their health is also affected as a result of polluted air and drinking water. In one sentence they are exploited, deprived, disempowered, marginalized and condemned to perpetual underdevelopment. Resource wealth has become resource curse to the people of the Niger Delta particularly for Delta State of Nigeria. This is highly connected to the various conflicts that have bedevilled the oil producing communities in recent past. The people are not happy as their environment has gradually been degraded and violated. The economic boom of Nigeria has become the doom of the oil bearing communities that sustain almost all socio-economic development in Nigeria. Finally, the environment cannot be devoid of human development. It is very important to sustainable human development. To give greater attention to preserving and using more wisely the environment and natural resources on which human development is hinged, oil resource, a very important aspect of development in Nigeria has to be managed responsibly.

\section{RECOMMENDATIONS}

Oil companies, and cooperate organizations need to establish projects that truly deal with the needs of the people. Such projects should include health facilities, institutions/training centres, communication facilities, good roads, electricity, 


\section{Omorede}

and pipe borne water. This should involve the peoples' participation.

The dominance of private and multinational sectors in the area notwithstanding, the Federal Government should on its part, have the political and economic will to ensure greater involvement of the people of the oil producing areas. Sustained job creation for the youth, provision of social amenities and infrastructures, will on one hand reduce unemployment, youth restiveness, and activities of doubtful values, and on the other hand, enhance peace and stability in the area.

Environmental degradation problems have been here for several years. It should not be sustained for the next generation to handle. Efforts to solve them should be taken more seriously. It is the responsibility of the government to protect the vulnerable group of the society. Environmental protection laws and policies should be carried out with utmost sense of responsibility. It is not just enough to enact stringent and lofty laws on papers alone. Government must ensure strict compliance of its policies by the oil companies.

The capability of the Monitoring Agencies should be enhanced to effectively carry out regular surveillance of the activities of participants in oil industry so as to sanction those found wanting if environmental issues are to be mitigated.

The people, whose lands and fishing areas have been taken over by oil resource exploration and exploitation, should adequately be compensated. This will ensure economic livelihood of the people. Compensation amongst other measures should include relocation to new environments (where possible) and capacity building that can enhance sustainable development. Considering the negative relationship between oil resource exploitation and the quality of Man's living, it becomes relevant that resource management in Nigeria should, involve externalities perspectives. Environmental Impact Assessment (EIA) should therefore, not be neglected in evaluating the costs that the oil exploitation participants are meant to pay.

NDDC and other palliative measures of environmental problems should properly be managed. This to some extent will contain social tension and protestations, alienation, and the issues of marginalization.

Government and oil producing industries should fast track the cleaning up of polluted areas due to oil spillage and gas flaring. A situation where it takes the companies up to 12 days to contain spill and four months later to begin cleanup operation which are set on fire causing further damage, like the case of Oruma in Balyesa state in 2005, should be avoided.

\section{REFERENCES}

Adekoya, J. A. (2003). Environmental effects of solid minerals mining. Journal of Physics Science, 625-640.

Ajakaiye, D. E. (1985). Environmental problems associated with mineral exploitation in Nigeria. Paper Presented at the $21^{\text {st }}$ Annual Conference of the Nigeria Mining and Geosciences Society, JOS, Nigeria.

Akogun, K. (2011). NDDC, A failure, says Mark. This Day, Retrieved November, 17, 2011, from http://www.thisdaylive.com/articles/nddc-a-failure-saysmark/102995.

Akpofure, E. A., Efere, M. L. \& Ayawei, P. (2000). The adverse effects of crude oil spills in the Niger delta, Nigeria: Urhobo Historical Society.

Arubi, E. (2007). Nigeria: Oil spill displaces 10 ljaw communities. Retrieved February 13, 2007, from http://www. corpwatch. org/article. php? id=14356

Auty, R. M. (1993). Sustaining development in mineral economies: The Resource Curse Thesis, London: Routledge.

Auty, R. M. (1998). Resource abundance and economic development: Improving the Performance of Resource Rich 
International Journal of Management, Economics and Social Sciences

Countries, Helsinki: UNU World Institute for Development Economics research.

Awodola, A. M. (1997). Drought and Desertification in Nigeria, in B. R. Sinhg, (ed.) Marginal of Marginal Lands in Nigeria proceeds of the $23^{\text {rd }}$ Annual Conference of the Soil Science Society of Nigeria, Sokoto, Nigeria, SSSN/ UDU.

Bankole, B. O. \& Owoseni, O. D. (2010). The environmental effects of indiscriminate disposal of waste in Akure metropolis of Ondo State, Nigeria, Proceeding of the forth African Regional Conference on Sustainable Development, Pre Degree Hall, Delta State University, Abraka, Delta State, Nigeria.

Bamet, R. J. \& Muller, R. E. (1974). Global Reach: The power of multinational corporation. New York: Simon and Schuster.

Baumol, W.J. \& W. G . Oates (1988). The theory of environmental policy (2nd ed.). Cambridge: Cambridge University Press.

Billon, P. (2001). The political ecology of war: Natural resources and armed conflict. Political Geography, 20(5): 561-584.

Camagni, R. (1998). Sustainable urban development: definition and reasons for a research programme. International Journal of Environment and Pollution, 10(1): 6-27.

CBN (1981). Statistical Annual Report. Central Bank of Nigeria ,Nigeria.

Coase R. H. (1960). The problem of social cost. Journal of Law and Economics, 3, 1-40.

Collier, P. \& Hoeffler, A. (2002). Greed and Grievances in Civil War. Oxford Economies Paper, 56

563-595

Creswell, J. W. (1998). Qualitative inquiry and research design: Choosing among five designs (3rd ed.). California: Sage.

Creswell, J.W. (2009). Research design: Qualitative, quantitative, and mixed methods approaches (3rd ed.). California: Sage.

Dam, K. W. (1976). Oil resources: who gets what how? Journal of Political Economy, 85(4): 882-884.

Efole. M. A. (2004). Environmental degradation \& economic impact of oil exploration in isoko land. 2nd National Convention of the Isoko Association of North America, New York: USA

Ekpo, O. B \& Udotong. (2004). Air quality, precipitation and corrosion studies of Mbo L. G A. Nigeria. International Journal of Environmental Issues, 2, 33-47.

Elvidge, C. D., Ziskin, D., Baugh, K. E., Tuttle, B. T., Ghosh, T., Pack, D. W. \& Zhizhin, M. (2009). A fifteen year record of global natural gas flaring derived from satellite data. Energies, 2(3): 595-622.

Emoyan, O. O., Akpoborie I. O. \& Akporkonor, E. E. (2008). The oil and gas industry and the Niger Delta: Implications for the environment. Journal of Applied Science Management, 12(3): 29-37.

Essoka, P. A., Ubogu, A. E. \&. Uzu, L. (2006). An overview of oil pollution and heavy metal concentration in warri area, Nigeria. Management of Environmental Quality: An International Journal, 17(2): 209-215.

Eteng, I. A. (1997). The Nigerian State, Oil Exploration and Community Interest: Issues and Perspectives. Nigeria: University of Port- Harcourt.

Fagade, S. O. (1981). An Assessment of the Impact of Pollution on the Fishes and Fisheries of Port- Harcourt, Nigeria, Niger Delta Development Authority.
Forsythe, R. (1996). The politics of oil in the Caucasus and Central Asia: Prospects for oil exploitation and export in the Caspian basin. Oxford: Oxford University Press.

Garland, H., Sandefur, C. A. \& Rogers, A. C. (1990). Deescalation of commitment in oil exploration: When sunk costs and negative feedback coincide. Journal of Applied Psychology, 75(6): 721-727.

Hardin, G. (1968). The Tragedy of the Commons. Science, 162(3859): 1243-1248.

Harris- Okon, E. (2011). Daily Independent, Lagos, April 25 ${ }^{\text {th }}$.

Ikporukpo, C. O. (1988). Managing Oil Pollution in Nigeria: Towards an interactive approach, In P.O. Sada, and F.O. Odemerho, (Eds.), Environmental Issues and Management in Nigeria Development: 224-229. Ibadan: Evans Brothers Nigeria.

Jaiyeoba, A. (2002). "Environment" . Africa Atlases: Atlas of Nigeria: 13-13. Paris: Les Editions.

Jimoh, H.I. \& Aghalino, S.O. (2000). Petroleum and environmental degradation: A perspective on government policies in Nigeria, In Jimoh, H.I. and Ifabiyi, I. P. (Eds.), Contemporary Issues in Environmental Studies: 238-244. Ilorin: Haytee Press and Publishing Co. Ltd.

Link, W. K. (1952). Significance of oil and gas seeps in world oil exploration. AAPG bulletin, 36(8): 1505-1540.

Marshall, A. (2009). Principles of economic (8th ed.). New York: Cosimo Inc.

Meade, J. (1973). The theory of economic externalities. Brill Archives.

Nehring, R. (1978). Giant oil fields and world oil resources. Rand Corporation Report R-2284 CIA.

Nigeria Galleria (2004). Delta State of Nigeria: Nigeria Information \& Guide Retrieved August 14, 2013from http://www.nigeriagalleria.com/Nigeria/States_Nigeria/Delt a_State

Nwankwo, J. N. \& Ifeadi, C. N. (1988). Environmental issues and management in Nigeria development. Case studies on the environmental impact of oil production and marketing in Nigeria. Ibadan: Evans Brothers Publishers.

Nwankwo, J. N. \& Ifeadi, C. N. (1986). Oil spill incidents in Nigerian petroleum industry: A critical analysis. Quarterly magazine of the NNPC, 8(4), Lagos: Public Affairs Department NNPC.

Nwilo, P.C. \& Badejo, O. T. (2005). Oil Spill Problems and Management in the Niger Delta. International Oil Spill Conference, Miami.

Nwilo, P. C. \& Badejo, O. T. (2007). Impacts and Management of Oil Spill Pollution Along the Nigerian Coastal Areas. Retrieved May 20, 2007, from https://www.fig.net/pub/figpub/ pub36/chapters/chapter_8.pdf.

Obi, C. (2009). Youths and the generational dimensions to struggles for resource control in the Niger delta, Dakar council for the development of social science research in Africa, in Retrieved May 6, 2009, from http://www.codesria.org./Links/ Publications/ monographs/CyrilObi.pdf

Ogoigbe, E. (2012). Bonga Oil: 64 Itsekiri communities write Shell SNEPCO, Warri, Monday Business Report, Jan, 9.

Odu, C. T. \& Offodum, I. (1986). Oil pollution and the environment. Bulletin of Science Association of Nigeria, 3(2): 282-289.

Omofonmwan, S. I. \& Odia, L. O. (2009). Oil exploitation and conflict in the Niger-Delta region of Nigeria. Journal of Human Ecology, 26(1): 25-30.

Owabukeruyele, S. W. (2000). Hydrocarbon exploitation, environmental degradation and poverty in the Niger delta 


\section{Omorede}

region of Nigeria. Paper presented at Lund University LUMES Program, Lund, Sweden.

Pigou, A. C. (1920). The economics of welfare. London: Macmillan and Co.

Ross, M. (2001). Extractive Sectors and the Poor. An Oxfam America Report,

Oct. http://www.polici.ucla.edu/faculty/ross/oxfam.

Rossman, R. B. \& Rallis, S. F. (1998). Learning in the field: An introduction to qualitative research. California: Sage.

Sachs, J. \& Warner, A. (2001). The curse of natural resources. European Economic Review, 45(4-6): 827-838.

Saro, K.W. (1991). Similia: Essays on anomic Nigeria, London: Saros International Publishers.

Sebastian, M.S. \& Hurting, A. K. (2004). Potential health impact of oil pollution on women living near oil fields. Pan American Journal of Public Health, 15(3): 205-211.

Stern, D. I., Common, M. S. \& Barbier, E. B. (1996). Economic growth and environmental degradation: The environmental Kuznets curve and sustainable development. World development, 24(7):1151-1160.

Turner, R. K., Pearce, D. \& Bateman, I. (1994). Environmental economics: An elementary introduction. Harvester Wheatsheaf.

Tyonongo, A.M. (2008). Economic implications of environmental degradation on the society. International Journal of Economics and Development Issues, 7(1): 3338.
Uchebuaku, M. (2006). International implication of kidnapping. Sunday Independent, 29, 3.

UN Agenda 21-Nigeria. (1997). Natural aspects of sustainable development in Nigeria, United Nations Commission on Sustainable Development, Nigeria. Retrieved November, 2011 from http://www.un.org/esa/agenda21/natlinfo/countr/Nigeria/n atur.htm.

UN System. (2001). Nigeria : Common Country Assessment, UN System in Nigeria, United Nations, New-York, NY March, p.79.

UNDP. (2006), Niger Delta Human Development Report, p. 229 .

Waas, T., Verbruggen, A. \& Wright, T. (2010). University research for sustainable development: definition and characteristics explored. Journal of cleaner production, 18(7): 629-636.

Wild, A. (1996). Soil and the Environment: An Introduction. New York: Cambridge University Press.

World Bank. (1995). Oil Companies and the Politics of Community Relations in Nigeria. Boiling Point, p.175. 